Original Contribution

\title{
HERPETOFAUNA OF STARA ZAGORA, SOUTHERN BULGARIA: SPECIES COMPOSITION AND DISTRIBUTION ALONG THE NATURAL HABITAT-URBAN AREAS GRADIENT
}

\author{
Dian Georgiev $^{1} *$, Dilian Georgiev ${ }^{2}$ \\ ${ }^{1}$ Department of Biology and Aquaculture, Faculty of Agriculture, Trakia University, Stara Zagora, \\ Bulgaria \\ ${ }^{2}$ Department of Ecology and Environmental Protection, Plovdiv University "Paisii Hilendarski", \\ Plovdiv, Bulgaria
}

\begin{abstract}
Herpetofauna of Stara Zagora city is characterized by exceptional species richness. In the this urban area and its adjacent territories, twenty-nine species from 13 families and four orders of class Amphibia and class Reptilia were found. From all species encountered in the studied region, 21 were established in suburban zones.

Ten species were registered in residential areas and their adjacent territories, and 18 species - in city parks. An obvious increase in number of species and their spread to the peripheral and central city areas was observed. The least number of species ( $5 \mathrm{sp}$.) was observed in construction areas, areas of intensive crop farming (6 sp.) and around administrative buildings (6 sp.).
\end{abstract}

Key words: Herpetofauna, Stara Zagora, Amphibia, Reptilia

\section{INTRODUCTION}

\section{Study area}

Stara Zagora city is located both at the Upper Thracian Plain and at the south slopes of Sarnena Sredna Gora Mts., Bulgaria. Due to the specific location of this urban area and its surroundings, various types of habitats exist having also a variety of ecological niches. Regardless of the fact the the city is not from the list of locations, important from herpetological point of view, the species described in Appendix 1 are encountered in the city and its vicinities. Analysis of the literature available (1) and personal observations, the rich herpetofauna is attributed to city's proximity to Sredna Gora Mts (most eastern ridge, called Sarnena Gora); the considerable number of recreation parks and gardens. The available source of food and the proper temperature/humidity is beneficial for some newts, toads, geckoes and other amphibian and reptilian species for their allover-year (even winter) activity (2).

\footnotetext{
*Correspondence to: Dian Georgiev, Department of Biology and Aquaculture, Faculty of Agriculture, Trakia University - Stara Zagora, dmihaylov@uni-sz.bg
}

\section{MATERIAL AND METHODS}

The Stara Zagora city area - urban part with its adjacent territories (settlements and villa areas), and adjasent agricultural lands (intensive crops and orchards), could be divided into the following zones (3-5):

SU (suburban) - urban areas and their surroundings with the following distinct zones: SU-RB: residential buildings (blocks, houses and the adjacent areas); SU-AB: administrative buildings (schools, kindergartens, universities, municipal administration, police, hospitals, libraries and adjacent areas); SU-WH: warehouses (municipal market storage facilities, warehouses in the industrial region, large car garages of hospitals, police department, fire department, of the Trakia university, warehouses of logistic companies and related areas); SU-C: construction works (buildings, civil engineering projects out of the city and related areas); SU-PG: recreational parks and gardens (Metropolitan Metodiy Kousev park, Zagorka park, Railway station garden, Samarsko Zname park, Stara Zagora city zoo); SU-MC: Cemetery and memorial complexes; 
R (rural) - land out of the city with distant cultivable areas (intensive crops, orchards) and the slopes of Sarnena Sredna Gora Mts used for tourism. The following rural zones could be defined:

R-SG: Slopes of Sarnena Sredna Gora Mts used for tourism (Stara Zagora Mineral Baths, Malka Vereya village, ecopath Zagorka Zmeevo village); R-IC: Intensive crop farmland (wheat, barley, rapeseed, sunflower, vegetable gardens of Deroni Ltd), near or at a distance from Stara Zagora; R-OG orchards.
GEORGIEV DIAN, et al. All the animals were registered as active representatives of established species during field investigations of authors or after signals from residential of administrative buildings, and warehouses. Two species Trachemys scripta and Lacerta praticola were indicated after being observed, and Pelobates syriacus balcanicus - as a species that could be encountered in the future in the Stara Zagora region as it was reported in the Kazanlashka valley by (6).

\section{RESULTS}

Table 1. Zones defined within the Stara Zagora area and species composition of established herpetofauna.

\begin{tabular}{|c|c|c|c|c|c|c|c|c|c|}
\hline Species & SU- RB & $\mathbf{S U}-\mathbf{A B}$ & $\mathbf{S U}-\mathbf{W H}$ & $\mathbf{S U}-\mathbf{C}$ & SU-PG & SU-MC & R-SG & $\overline{R-I C}$ & $\mathbf{R - O G}$ \\
\hline S. salamandra & & & & & & & + & & \\
\hline T. karelinii & & & & & + & & + & & \\
\hline T. vulgaris & & & & & + & & + & & \\
\hline B.bombina & & & & & + & & & & \\
\hline B. bufo & & & + & & + & + & + & & + \\
\hline B. viridis & + & + & + & + & + & + & + & & \\
\hline B. bombina & & & & & & & & + & + \\
\hline H. arborea & + & & & & + & + & + & & + \\
\hline R. dalmatina & + & & & & + & + & + & & \\
\hline R. temporaia & & & & & & & + & & \\
\hline R. ridibunda & + & & + & & + & + & + & & \\
\hline E. orbicularis & & & & & + & & + & & \\
\hline T. scripta & & & & & + & & & & \\
\hline T. hermanni & & & & & & & + & & \\
\hline T. graeca & & & & & & & + & & \\
\hline C. kotsihyi & + & + & + & + & + & + & + & & \\
\hline A. kitaibeli & & + & & & + & + & + & & \\
\hline L. trilineata & & & & & + & + & + & + & + \\
\hline L. praticola & & & & & & & + & & \\
\hline L. viridis & + & & & + & + & + & + & + & + \\
\hline P. muralis & + & & + & + & + & + & + & & \\
\hline P. taurica & + & & & & + & + & + & & + \\
\hline N. natrix & + & + & + & & + & & + & & \\
\hline N. tessellata & & & & & + & & + & & \\
\hline C. caspius & + & + & + & + & & + & + & + & + \\
\hline E. longissima & & & + & & + & + & + & & + \\
\hline E. sauromates & & & & & & & + & + & + \\
\hline C. austriaca & & & & & & & + & & \\
\hline V. ammodytes & & + & + & & & + & + & + & + \\
\hline
\end{tabular}

On the territory of Stara Zagora city and region, 28 autochthonous amphibian and retiles species, as well as one invasive with unclear status (Trachemys scripta) were encountered. The species Pelobates syriacus balcanicus also, possibly occurs in the surroundings of Stara Zagora city in the lowland areas (the 
species was reported from Kazanlashka valley and Upper Thracian Lowland by (6).

Their zone distribution was as followed:

SU-RB - 10 species; SU-AB - 6 species; SUWH - 9 species; SU-C - 5 species; SU-PG - 18 species; SU-MC - 14 species; R-SG - 26 species; R-IC - 6 species; R-OG - 10 species.

\section{DISCUSSION}

The most numerous species were found in the slopes of Sarnena Sredna Gora, most probably because of the existence of proper habitats and not so disturbed nature. From the total of 28 amphibians and reptiles, 26 representatives of the herpetofauna were registered here. Bombina bombina, which is a lowland species, was not observed in the water basins of Sarnena Gora Mts (7). The fire-bellied toad inhabits the lower Sazliyka River and Merichlerska River basins - the end points of spreading of the animal in the Stara Zagora field. In the city region, it was observed in canals and puddles in "Zora" residential area, and around Zagore village. E. sauromates was not found out on the slopes of Sarnena Gora as it adheres to hills and plains with grass and bush vegetation. The Blotched snake was not detected in urban areas during the last ten years. At about a decade before, these snakes
GEORGIEV DIAN, et al.

were common in the "Kazanski" residential area, near to the canal, as well as in the industrial area (personal observation). During the past 8 years, several car wash facilities and a brook were built along the canal, which altered the water quality and what is more, the riparian vegetation. Later, the natural vegetation in the industrial zone was changed and riparian zones were built. Barrens (with grass vegetation) in the city surroundings still harboured Blotched snake populations. The snake has been observed in orchards, and even in house yards of the near-by to the city, Hrishteni village, and could be observed at the foothills of Sarnena Gora Mts.

In the city parks and gardens, 18 species were known to occured. T. scripta was registered in the Zagorka lake. There was evidence for releasing specimens in the artificial lake "Zagorka" but without establishing a breeding population there.

Despite that forest zones and park forest habitats were of similar types, a major part of city parkswere in the city centre or in densely populated parts of the city. A substantial number of species (14 sp.) were registered in the cemeteries and memorial complexes (Figure 1).

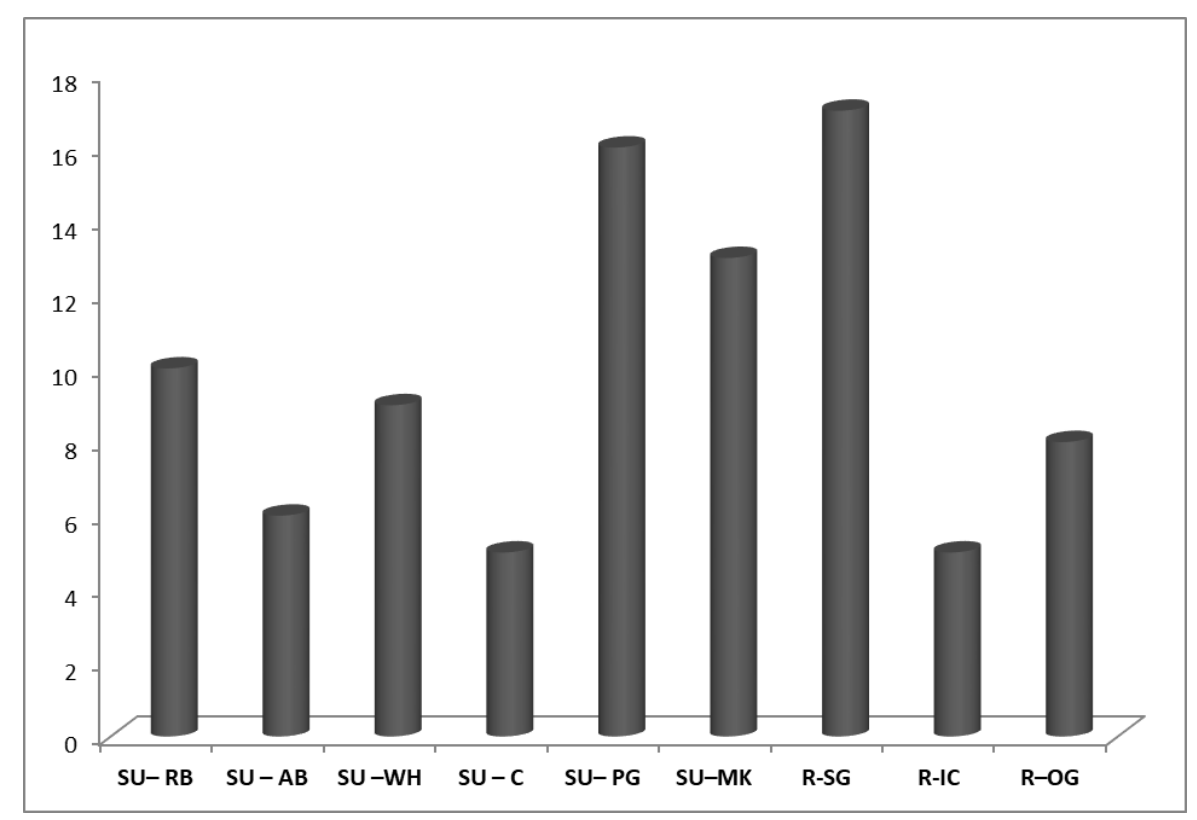

Figure 1. Distribution of amphibians and reptiles in the region of Stara Zagora by zones.

Ten of all detected species were encountered around residential buildings and their vicinities. If the possible reasons for the occurrence of many amphibian and reptile species in recreational gardens (18 sp.) and cemeteries $\left(\begin{array}{ll}14 & \text { sp. }\end{array}\right)$ were the specific vegetation and temperature amplitudes, the most important factor in residential areas was probably the good source of food. City, as a habitat, offers numerous populations of insects and rodents, being a food source of some amphibians and reptiles. In the city environments, herpetobionts found unique shelters and ambient temperature and 
humidity, corresponding to the ecological preferences of some species.

Similar number of species were observed in construction work areas (5 sp.) and intensive crop farmland $(6 \mathrm{sp}$.) despite the fact that both had only two species in common $(C$. caspius and $L$. viridis). The reasons could be possibly searched in the ecological factors combination in the two zones. Construction sites and intensive crops land were short-term habitats as both undergo substantial changes in time. Nevertheless, during the stasis (evening for construction sites and the periods between land cultivation), these zones are relatively calm with respect to human presence and offer temporary shelters for the animals. There, the animals could be protected from intense road traffic, during migration from one habitat to another, and in city environment - to avoid human presence. A typical example was the kindergarten in "Zora" residential area during 2009. Being located in the middle of a distant residential area from the city centre, the place became proper shelter for snakes at night. The monitoring found out (8) that sewerage system of the building favoured numerous rats and mice, e.g. the place maintained also a constant food source.

Warehouses and orchards had comparable number of representatives in zones 9 sp. and 10 sp. Data presented by (7) affirmed that species for Stara Zagora and the region lived close to habitats provided by orchards at different stages of the species' development. Also, the heat, humidity, sunlight intensity was beneficial for species in these zones during the different parts of the day.

An interesting fact was the substantial number of amphibians and reptiles in warehouses. In the area, several cases of presence of these species in warehouses were registered. The workers alarmed mostly the presence of snakes, whereas geckos and frogs were paid little attention.

Since 2004 to several snake specimens were recorded in warehouses of gas stations (3 cases), courier services (2 cases), and warehouses of the Trakia University (4 cases).

\section{CONCLUSIONS}

The herpetofauna of the Stara Zagora city and its vicinities was characterized by relatively high species richness. From the 29 species found in the study area, 21 or $72 \%$ were registered in the city suburban zones. An obvious increase in number of species and their spread to the peripheral and central city areas was recorded. This was probably not associated with an exclusive role of any of the ecological factors, and is a matter of future detailed investigations.

Appendix

Herpetofauna of Stara Zagora, species composition and distribution along the natural habitaturban areas gradient

The described species composition is as per (7).

\section{Class AMPHIBIANS - AMPHIBIA}

Subclass Caudata (Urodela)

Family Salamandridae

Fire salamander - Salamandra salamandra

Southern crested newt - Triturus karelinii

Smooth newt - Triturus vulgaris

Subclass Tailless amphibians (frogs)

Family Fire-bellied toads - Bombinatoridae

European fire-bellied toad - Bombina bombina

Family European spadefoot toads - Pelobatidae

Syrian spadefoot - Pelobates syriacus balcanicus**

Family Bufonidae

Common toad - Bufo bufo

European green toad - Bufo viridis

Family Tree frogs - Hylidae

European tree frog - Hyla arborea

Family True frogs - Ranidae

Agile frog - Rana dalmatina

European common frog - Rana temporaia

Marsh frog - Rana ridibunda 
Class REPTILES - REPTILIA

Subclass Turtles

Family Pond turtles - Emydidae

European pond turtle - Emys orbicularis

Pond slider - Trachemys scripta

Family Tortoises - Testudinidae

Hermann's tortoise - Testudo hermanni

Spur-thighed tortoise - Testudo graeca

Subclass Scaled reptiles - Squamata

Order LIZARDS - SAURIA

Family Geckos - Gekkonidae

Kotschy's gecko - Cyrtodactylus kotschyi

Family Skinks - Scincidae

European copper skink-Ablepharus kitaibeli

Family True lizards - Lacertidae

Meadow lizard - Lacerta praticola

Balkan green lizard - Lacerta trilineata

European green lizard - Lacerta viridis

Common wall lizard - Podarcis muralis

Balkan wall lizard - Podarcis taurica

Family Colubrid snakes - Colubridae

Caspian whipsnake - Coluber caspius

Aesculapian snake - Elaphe longissima

Blotched snake - Elaphe sauromates

Smooth snake - Coronella austriaca

Grass snake - Natrix natrix

Dice snake - Natrix tessellata

Family Vipers - Viperidae

Horned viper - Vipera ammodytes

*Trachemys scripta - There is evidence for releasing specimens in the artificial lake "Zagorka" but without establishing a breeding population there.

**The species Pelobates syriacus balcanicus, possibly occurs in the surroundings of Stara Zagora city in lowland areas (the species was reported from Kazanlashka valley and Upper Thracian Lowland by Mollov et al., 2007).

\section{REFERENCES}

1. Georgiev D., Reptiles and Amphibians in Our Home. Terraristic for beginners. Enyovche Publ. 75 p., 2010.

2. Mollov I., Georgiev D., Basheva S. Is the Kotschy's Gecko Mediodactylus kotschyi (Steindachner, 1870) (Reptilia: Gekkonidae) active during the winter? ZooNotes, 84: 1-3, 2015.

3. Irikov A., Georgiev D., Species composition, distribution of habitats, zoogeographical structure and origin of malacofauna of the Stara Zagora city. Research Works of the Plovdiv University Paisiy Hilendarski, 38, 6, 5-16, 2002.

4. Dedov I., Effect of urbanisation on fauna and communities of gastropods (Gastropoda, Mollusca) in Sofia city. PhD thesis abstract - CLGE-BAS, 44 p., 2002.

5. Mollov I., D. Georgiev, B. Todorova, S. Stoycheva, I. Velcheva, B. Nikolov. A Review of the Influence of the Urbanization on the Vertebrate Fauna of the City of
Plovdiv. - Biotechnology \& Biotechnological Equipment, 23(2 Special Edition): 242-245, 2009.

6. Mollov I., G. Popgeorgiev, B. Naumov, D. Georgiev. New distributional data about the eastern spadefoot (Pelobates syriacus balcanicus Karaman, 1928) in Bulgaria. - Scientific researches of the Union of Scientists - Plovdiv, Series B. Natural Sciences and the Humanities, Vol. VIII. ISSN 1311-9192, Technics, Technologies, Natural Sciences and Humanities Session, 26 October 2006, pp. 132-136, 2007 (In Bulgarian).

7. Beshkov, V.; Nanev, Amphibians and Reptiles in Bulgaria, PenSoft Publ, Sofia Moscow, 120 p, 2002.

8. Georgiev D. Diet of the Golden Eagle (Aquila chrysaetos) (Aves: Accipitridae) in Sarnena Sredna Gora Mountains (Bulgaria). - Ecologia Balkanica, 1: 95-98, 2009. 